\title{
EKSPLOITASI SUMBERDAYA LINGKUNGAN DAN KELESTARIAN SITUS ARKEOLOGI: KASUS GUA PAYUNG YANG TERABAIKAN DAN HILANG
}

\author{
Nia Marniati Etie Fajari
}

Balai Arkeologi Banjarmasin, Jalan Gotong Royong II, RT 03/06, Banjarbaru 70711, Kalimantan Selatan; Telepon (0511) 4781716; Facsimile (0511) 4781716; email: niamarniatief@yahoo.com

Artikel masuk pada 1 April 2013

Artikel direvisi pada 25Agustus 2013

Artikel selesai disunting pada 16 September 2013

\begin{abstract}
Abstrak. Gua Payung adalah salah satu dari sekian banyak gua hunian prasejarah di kawasan karst Mantewe yang telah dilaporkan oleh Balai Arkeologi Banjarmasin. Penelitian pada 2006 dan 2012 telah menghasilkan sejumlah data arkeologi yang menunjukkan periode hunian dari sekitar 2970 \pm 130 BP dan 3070 \pm 130 BP. Namun, keberadaan Gua Payung yang memiliki nilai penting bagi perkembangan masa prasejarah di Kalimantan, tidak sejalan dengan kelestariannya sebagai situs cagar budaya. Gua Payung saat ini berada dalam kondisi yang rusak akibat penggalian tanah endapan gua dan kotoran kelelawar oleh masyarakat setempat untuk keperluan perkebunan sawit. Penelitian ini membahas faktor-faktor yang melatarbelakangi kerusakan masif di Gua Payung dengan menguraikan rangkaian sebab-akibat yang terjadi karena beberapa aspek. Alur yang telah disusun kemudian menjadi dasar untuk menyusun sebuah tawaran solusi dalam mengurangi laju kerusakan gua-gua hunian prasejarah lainnya di kawasan karst Mantewe.
\end{abstract}

Kata kunci: Gua Payung, Mantewe, karst, prasejarah, cagar budaya, pelestarian, sumberdaya

Abstract. THE EXPLOITATION OF ENVIRONMENTAL RESOURCES AND SUSTAINABILITY OF ARCHAEOLOGICAL SITE: THE CASE OF PAYUNG CAVE, NEGLECT AND LOST. Payung cave is one of the many prehistoric dwelling caves in the karst region of Mantewe which has been reported by the Archaeological Institute of Banjarmasin. Research in 2006 and 2012 have resulted in a number of archaeological data shown the occupancy around 2970 $\pm 130 \mathrm{BP}$ and $3070 \pm 130 \mathrm{BP}$. However, the existence of the Payung Cave which has much significancy for the development of the prehistoric period in Kalimantan, is not in line with its sustainability as a cultural heritage site. The Payung cave is currently damage due to sediment excavation and bat droppings by local community for the purpose of oil palm plantations. This study discusses the factors behind the massive damage in the Payung Cave by outlining a series of cause-effect that occurs due to several aspects. Groove that had been developed subsequently became the basis for preparing a solution in a bid to reduce the damaging rate of the prehistoric caves occupancy on the other karst region of Mantewe.

Keywords : Payung Cave, Mantewe, karst, prehistoric, cultural preservation, conservation, cultural resource

\section{A. Pendahuluan}

\section{Latar Belakang}

Masa prasejarah di wilayah Kalimantan gaungnya tidak sekeras gambaran kisah di lokasi lain seperti di Jawa dan Sumatera. Di Pulau Jawa, serangkaian penelitian yang intesif telah dilakukan secara menyeluruh di berbagai situs prasejarah. Gambaran kehidupan prasejarah yang nyaris lengkap dapat dilihat pada situs di kawasan Sangiran Dome dan deretan pegunungan karst Gunung Sewu. Selain itu, kawasan Sangiran telah ditetapkan menjadi world heritage sejak tahun 1996. Oleh sebab itu, perhatian pemerintah baik pusat maupun daerah terhadap penelitian arkeologi dan pelestarian situs di lokasi tersebut sangatlah besar. Sementara itu, situs-situs prasejarah di Kalimantan yang sudah terdokumentasi terdapat di kawasan perbukitan karst Mantewe, karst Batubuli dan aliran Sungai Riam Kanan di Propinsi Kalimantan Selatan; serta kawasan karst di perbukitan Sangkulirang dan Mangkalihat di Propinsi Kalimantan Timur. Penelitian secara menyeluruh baru dilakukan di Gua Babi yang terletak di perbukitan karst Batubuli di Kabupaten 
Tabalong. Hasil penelitian Gua Babi menggambarkan bahwa aktivitas manusia telah terjadi sejak 6000 tahun yang lalu dengan teknologi rekayasa alat batu dan pembuatan gerabah. Mereka mengandalkan sumber energi berupa kerang, binatang, dan berbagai jenis tumbuhan yang terdapat di sekitarnya untuk bertahan hidup (Widianto dan Handini 1999).

Selanjutnya, temuan baru tentang jejak manusia prasejarah kembali ditemukan di kawasan karst Mantewe di Kabupaten Tanah Bumbu. Survei arkeologi yang dilakukan di daerah tersebut berhasil mendokumentasi gua-gua yang diasumsikan pernah menjadi hunian manusia prasejarah. Kurangnya perhatian dan penelitian yang belum terfokus menyebabkan kawasan karst Mantewe yang memiliki potensi besar dalam arkeologi prasejarah sedikit terabaikan. Salah satu situs dengan temuan data arkeologi adalah Gua Payung di Gunung Batu Tanjak, Desa Bulurejo, Kecamatan Mantewe. Penelitian di Gua Payung dilakukan pertama kali oleh tim Balai Arkeologi Banjarmasin pada 2006. Ekskavasi yang dilakukan di Gua Payung kala itu berhasil menemukan sejumlah data artefak dan ekofak, yang berupa fragmen gerabah, artefak batu, tulang, dan kerang, serta cangkang kerang, dan fragmen tulang binatang (Fajari 2010). Berdasarkan hasil penelitian tersebut diketahui bahwa Gua Payung pernah menjadi hunian manusia pada masa prasejarah. Analisis terhadap temuan gerabah dari penelitian tahun 2006 memberikan gambaran bahwa okupasi Gua Payung pada masa itu dilakukan oleh kelompok penutur bahasa Austronesia (Fajari 2010). Selanjutnya, penelitian di Gua Payung dilaksanakan kembali pada tahun 2012 yang didanai oleh Granucci Grant periode 2011. Rentang waktu yang begitu panjang dengan penelitian sebelumnya memberi dampak buruk yang tidak diharapkan. Gua Payung yang menyimpan data arkeologi penting pada masa prasejarah berada pada kondisi yang sangat memprihatinkan akibat aktivitas pengolahan lahan perkebunan kelapa sawit warga di sekitar Gua Payung. Meskipun demikian, sejumlah kecil data artefak dan ekofak masih dapat didokumentasikan secara sistematis.

Berdasarkan penjelasan di atas, permasalahan yang akan diungkap dalam makalah ini adalah faktor apa yang menjadi penyebab kerusakan masif pada situs prasejarah di Gua Payung? Penjelasan mengenai faktor-faktor penyebab kerusakan tersebut diharapkan dapat menghasilkan strategi dan rekomendasi sebagai upaya untuk menjaga kelestarian situs-situs arkeologi di kawasan karst Mantewe serta di daerah lainnya.

\section{Tinjauan Pustaka}

Perbukitan karst Mantewe di Kabupaten Tanah Bumbu, Kalimantan Selatan merupakan salah satu kawasan karst yang diketahui memiliki gua-gua hunian dari masa prasejarah. Sementara ini, perlindungan dan pelestarian menyeluruh terhadap potensi arkeologi di kawasan tersebut belum dilakukan. Menurut Samodra $(2001,6)$ kawasan karst merupakan perpaduan antara unsur-unsur morfologi, kehidupan, energi, air, gas, tanah, dan batuan yang membentuk satu kesatuan sistem yang utuh. Gangguan terhadap salah satu unsur akan berpengaruh pada keseluruhan sistem. Selain memiliki potensi sumberdaya alam, kawasan karst juga menyimpan potensi arkeologi yang terdapat di gua atau ceruk alam yang menjadi pemukiman manusia prasejarah. Lingkungan fisik dan biofisik yang rapuh, serta beragam potensi yang dimiliki, menyebabkan semua kegiatan yang berdampak buruk harus ditiadakan. Pengelolaan dan pelestarian kawasan karst, terutama yang berkaitan dengan tinggalan arkeologi, sesuai dengan rumusan yang telah disusun oleh Kementerian Lingkungan Hidup, yaitu (1) penyamaan persepsi di antara sektor-sektor pembangunan terkait, dengan memperhatikan aneka permasalahan yang ada; (2) penyeragaman pola pengelolaan yang mendasarkan pada jenis dan karakteristik masing-masing kawasan; (3) penetapan bentuk perlindungan yang disesuaikan dengan karakteristik kawasan; dan (4) penetapan metode analisis yang cocok untuk penentuan jenis perlindungan dan konsep penanganannya (Kasri dkk 1999, dalam Samodra 2001, 11).

Hal tersebut senada dengan yang tercantum dalam Undang Undang No 10 Tahun 2011 tentang Cagar Budaya pasal $9^{1}$ dan $10^{2}$ yang menyebutkan kriteria kawasan atau situs yang dapat disebut Cagar Budaya. Sesuai dengan isi pasal tersebut, kawasan karst yang memiliki gua/ceruk hunian masa prasejarah

Pasal 9 menyebutkan bahwa lokasi dapat ditetapkan sebagai situs Cagar Budaya apabila (a) mengandung Benda Cagar Budaya, Bangunan Cagar Budaya, dan/atau struktur Cagar Budaya; (b) menyimpan informasi kegiatan manusia pada masa lalu.

2 Pasal 10 menyebutkan bahwa Satuan ruang geografis dapat ditetapkan sebagai Kawasan Cagar Budaya apabila:

a. mengandung 2 (dua) Situs Cagar Budaya atau lebih yang letaknya berdekatan;

b. berupa lanskap budaya hasil bentukan manusia berusia paling sedikit 50 (lima puluh) tahun;

c. memiliki pola yang memperlihatkan fungsi ruang pada masa lalu berusia paling sedikit 50 (lima puluh) tahun;

d. memperlihatkan pengaruh manusia masa lalu pada proses pemanfaatan ruang berskala luas;

e. memperlihatkan bukti pembentukan lanskap budaya; dan

f. memiliki lapisan tanah terbenam yang mengandung bukti kegiatan manusia atau endapan fosil. 
merupakan kawasan situs Cagar Budaya yang harus dilindungi dan dilestarikan. Ketentuan tersebut juga terdapat dalam Keputusan Menteri ESDM No 1456.KI 20/MEM/2000 tentang pedoman pengelolaan kawasan karst yang menyebutkan bahwa kawasan karst yang memiliki gua dengan speleotem aktif dan/atau peninggalan sejarah yang berpotensi untuk pengembangan objek wisata dan budaya merupakan kawasan kelas I yang harus bebas dari segala bentuk aktivitas penambangan (Sugiyanto 2008, 135-136).

Penetapan kawasan yang mengandung cagar budaya sebagai kawasan lindung nasional juga tercantum dalam Peraturan Pemerintah Republik Indonesia No 26/2008 tentang Rencana Tata Ruang Wilayah Nasional. Pada pasal 51 disebutkan bahwa salah satu dari kriteria kawasan lindung nasional adalah kawasan suaka dan pelestarian alam dan cagar budaya (PPRI No 26/2008, 30). Sementara itu, pasal 101 menyebutkan mengenai peraturan zonasi untuk kawasan cagar budaya dan ilmu pengetahuan yang disusun dengan memperhatikan pemanfaatan untuk penelitian dan pendidikan serta ketentuan pelarangan bentuk kegiatan dan pendirian bangunan yang tidak sesuai dengan fungsi kawasan.

Meskipun telah banyak perangkat peraturan yang mengatur bentuk pelestarian kawasan cagar budaya, sistem pengelolaan sumber daya arkeologi di Indonesia belum berjalan dengan baik. Konflik atas nama pembangunan yang menunjuk pada proses pertikaian sering muncul dalam upaya-upaya pelestarian cagar budaya. Konflik muncul karena pelaku pembangunan beranggapan bahwa pelestarian cagar budaya adakalanya menghambat upaya pencapaian kebutuhan dan kepentingan pembangunan nasional. Sementara itu, aspirasi dan keterlibatan masyarakat di sekitar situs belum banyak dilibatkan dalam kegiatan pengelolaan dan pelestarian cagar budaya. Hal tersebut disebabkan karena sistem pengelolaan sumber daya arkeologi di Indonesia masih bersifat arkeologi pemerintah dan belum bersifat publik (Sulistyanto 2009, 259-264).

\section{Metode Penelitian}

Penelitian ini dilakukan dengan pengamatan dan analisis terhadap data arkeologi yang ditemukan. Analisis yang dilakukan adalah pengamatan awal yang meliputi klasifikasi berdasarkan jenis, bentuk, dan teknologi. Selain pengamatan terhadap data arkeologi, dilakukan juga pengamatan terhadap kondisi lingkungan serta potensi lahan di Gua Payung dan kawasan di sekitarnya. Hasil pengamatan tersebut dikelompokkan ke dalam ancaman yang sudah dan yang belum terjadi terkait dengan kerusakan situs. Wawancara mendalam dengan warga yang beraktivitas di sekitar Gua Payung dilakukan untuk menghimpun data mengenai pemanfaatan sumberdaya alam di lokasi yang diasumsikan dapat menjadi penyebab kerusakan situs. Hasil dari studi tersebut dapat menjadi acuan untuk pencegahan kasus serupa di situs-situs di daerah lain.

\section{B. Budaya Prasejarah Gua Payung}

Ekskavasi Gua Payung yang dilakukan pada tahun 2006 menghasilkan sejumlah data artefaktual dan ekofak yang cukup signifikan. Jenis artefak yang ditemukan adalah artefak batu, fragmen gerabah, dan perhiasan kerang. Artefak batu yang ditemukan berupa serpihan, serpih, batu inti, dan bilah (Foto 1). Jenis bahan yang digunakan antara lain rijang, kalsedon, dan andesit. Pengelompokan jenis artefak batu tersebut dilakukan berdasarkan morfologi awal, sedangkan pengamatan lebih detil terhadap ciri-ciri teknologi dan bekas pemakaian belum dilakukan. Sementara itu, analisis gerabah Gua Payung hasil penelitian tahun 2006 menghasilkan klasifikasi bagian yang terdiri atas fragmen tepian, fragmen badan, fragmen karinasi, fragmen bagian tutup atau pegangan tutup, dan fragmen dasar gerabah. Berdasarkan hasil tersebut diketahui bahwa ragam gerabah Gua Payung yaitu berupa wadah periuk yang kemungkinan digunakan untuk keperluan sehari-hari. Keberadaan gerabah Gua Payung merupakan indikasi adanya jejak aktivitas para penutur Austronesia di wilayah tersebut (Fajari 2010).

Selain kemiripan ciri teknologi gerabahnya, jejak Austronesia juga tampak pada sejumlah artefak kerang yang ditemukan di Gua Payung. Artefak tersebut berupa perhiasan kerang yang terdiri atas sebuah gelang tangan, pecahan cakram kerang, dan potongan gelang kerang (Foto 2). Gelang tangan yang ditemukan dalam keadaan utuh tersebut berukuran kecil yang kemungkinan merupakan gelang untuk anak-anak. Pecahan cakram kerang diperkirakan sebagai bagian dari bandul kalung yang telah pecah. Perhiasan kerang tersebut memiliki kemiripan dengan yang ditemukan di Situs Buwawansi dan Situs Talepakemalai di Pulau Mussau. Di situs tersebut, benda-benda kerang baik yang berupa perhiasan maupun bukan merupakan benda berharga yang memiliki nilai sebagai alat tukar. Sementara itu, analisis terhadap keberadaan perhiasan kerang di Gua Payung belum dilakukan secara mendalam (Fajari 2010). Sementara itu, data ekofak yang ditemukan di Gua Payung terdiri atas fragmen tulang binatang dan cangkang kerang diasumsikan sebagai sampah sisa makanan.

Berselang enam tahun kemudian, penelitian Gua Payung kembali dilakukan untuk menambah data 


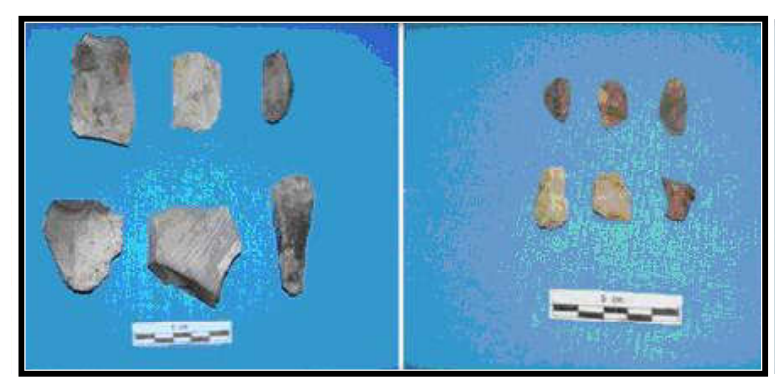

Foto 1. Artefak batu Gua Payung : alat serpih-bilah (kiri) ; alat serpih (kanan)(Dok. Balai Arkeologi Banjarmasin, 2010).

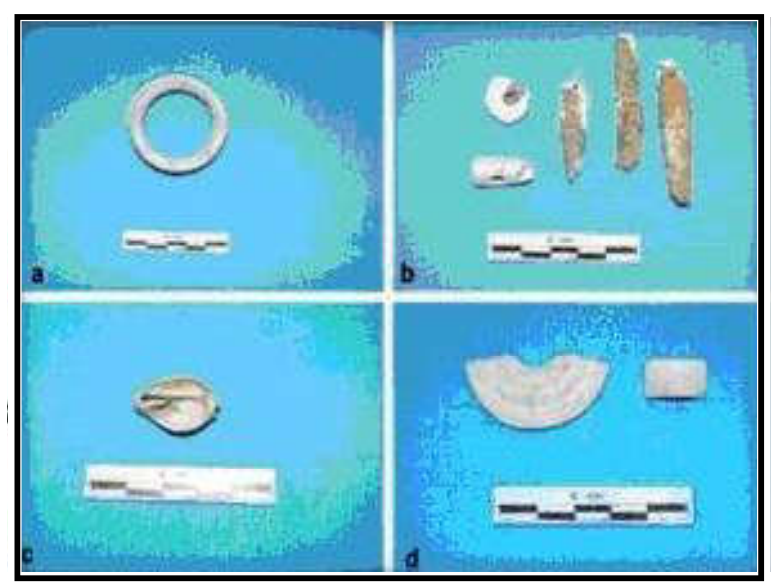

Foto 2. Jenis artefak kerang Gua Payung: a) gelang kerang ; b) perhiasan dari batu kapur : c) kerang cowrie ; d) fragmen gelang kerang (Dok. Balai Arkeologi Banjarmasin, 2010).

mengenai kehidupan manusia prasejarah pada masa itu. Sayang sekali, kondisi permukaan lantai gua sudah mengalami perubahan drastis akibat aktivitas penambangan guano dan tanah untuk perkebunan kelapa sawit. Dampaknya adalah banyak data arkeologi di Gua Payung ikut hilang bersama dengan tanah yang diambil. Penggalian tanah yang dilakukan oleh warga hanya menyisakan sedikit lantai gua yang belum teraduk. Bagian yang belum teraduk inilah yang diekskavasi, terdiri atas empat kotak tes pit, yaitu TP 1, TP 2, TP 3, dan TP 4. Data arkeologi hasil ekskavasi tersebut terdiri atas artefak berupa fragmen gerabah, artefak batu, dan artefak kerang; serta ekofak berupa fragmen tulang binatang, fragmen cangkang kerang, oker, dan fragmen arang. Analisis pertanggalan yang dilakukan terhadap cangkang kerang dari TP 1 layer 2 dan 3 menghasilkan angka 2970 \pm 130 BP (layer 2) dan $3070 \pm 130$ BP (layer 3) (Fajari dan Kusmartono 2012).

Temuan arkeologi paling banyak terdapat pada kotak TP 1. Hal tersebut disebabkan oleh kondisi TP 1 berada pada ambang pintu gua sisi barat dan belum mengalami penggalian liar. TP 2 berada pada ambang pintu gua sisi timur dan kondisi tanah di sekitarnya sudah tergali oleh aktivitas penambangan guano dan tanah. Sementara kotak TP 3 yang berada di bagian dalam ruang gua, meskipun tidak ikut tergali oleh aktivitas tambang, temuan yang didapat tidak terlalu banyak. Kotak TP 4 yang berada di bawah dinding gua di dekat mulut barat, sebagian tanahnya juga sudah teraduk.

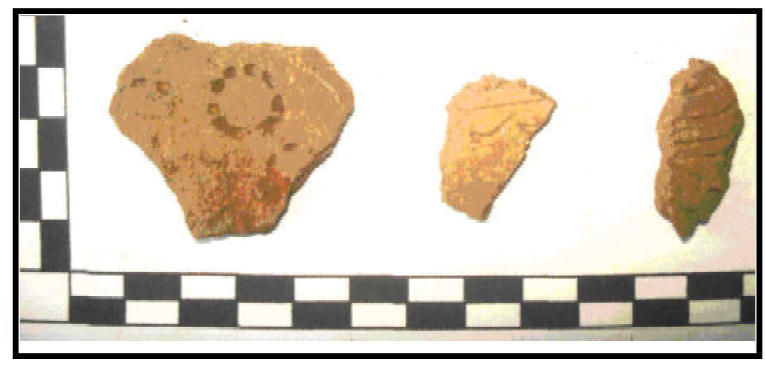

Foto 3. Fragmen badan gerabah berhias dari Gua Payung, dari kiri-kanan: dekorasi teknik tusuk dengan motif lingkaran; teknik gores dengan motif pola geometri garis lurus dan lengkung; teknik gores dengan motif garis (Dok. Balai Arkeologi Banjarmasin, 2012).

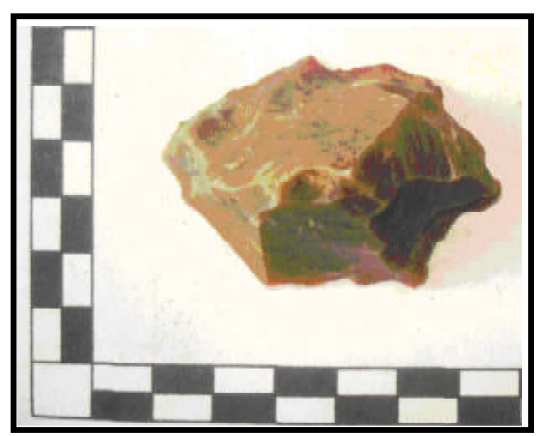

Foto 4. Batu inti dari Gua Payung (Dok. Balai Arkeologi Banjarmasin, 2012).

Berdasarkan analisis awal, gerabah Gua Payung diklasifikasikan ke dalam empat kelompok, yaitu gerabah berhias, gerabah polos, gerabah slip merah, dan gerabah upam hitam. Teknik hias yang dilakukan adalah teknik tusuk, tekan, dan upam. Sementara ittu, motif dekorasinya terdiri atas motif geometri berupa garis horizontal dan vertikal, segitiga, lingkaran, dan kotak, serta bentuk meander (Fajari dan Kusmartono 2012). Gabungan dari berbagai garis geometri tersebut membentuk pola hias seperti duri ikan, zig zag, dan bulatan matahari (Foto 3).

Klasifikasi awal terhadap artefak batu Gua Payung menghasilkan enam kelompok artefak, yaitu serpih (flakes), bilah (blades), batu inti (cores, Foto 4), lancipan batu (points), batu pukul (hammerstones), dan limbah batu (debitages). Sejumlah besar limbah batu terpecah 
akibat adanya aktivitas pembakaran. Pengamatan awal terhadap serpih dan bilah menunjukkan bahwa kedua jenis alat tersebut tidak disiapkan dengan teknologi khusus, melainkan hanya dipangkas secara sederhana untuk membentuk tajaman (Fajari dan Kusmartono 2012).

Fragmen tulang binatang merupakan temuan yang paling banyak terdapat di kotak-kotak ekskavasi. Selain tulang, ditemukan juga fragmen gigi dan rahang. Analisis awal terhadap tulang dan gigi tersebut menghasilkan beberapa jenis hewan, di antaranya adalah Macaca sp., Bovidae, Cervidae, Testudinae, Suidae, Ursidae, Aves, dan fishes. Tulang-tulang tersebut diasumsikan sebagai sisa makanan manusia Gua Payung. Selain tulang sisa makanan, ditemukan juga alat-alat tulang berupa lancipan dan sudip tulang (Fajari dan Kusmartono 2012). Jenis limbah makanan lain di Gua Payung adalah kerang yang ditemukan dalam jumlah yang signifikan. Jenis kerang yang menjadi konsumsi adalah kerang air tawar dari famili Thiaridae, Pupinidae, dan Lymnaeidae. Selain kerang air tawar, ditemukan juga jenis kerang air laut, yaitu cowry dan fragmen Tridacna, meski jumlahnya tidak banyak (Fajari dan Kusmartono 2012). Berdasarkan jumlahnya yang tidak banyak, memberikan gambaran bahwa kerang laut tidak dikonsumsi untuk sumber makanan.

Keberadaan tulang binatang dan cangkang kerang menunjukkan bahwa pendukung budaya Gua Payung melakukan perburuan untuk mendapatkan makanan. Mereka berburu binatang dari jenis Macaca sp., Bovidae, Cervidae, Suidae, Ursidae, dan Aves. Selain berburu, manusia Gua Payung juga melakukan aktivitas penangkapan ikan dan kura-kura serta mengumpulkan kerang air tawar di sungai yang berada di dekat gua. Dalam melakukan aktivitas tersebut, mereka lebih banyak menggunakan peralatan dari batu. Hal tersebut ditunjukkan dengan melimpahnya temuan artefak batu dengan bekas pengerjaan pada sisi-sisinya. Bekas pengerjaan tersebut berupa pangkasan-pangkasan yang dikerjakan pada batu untuk menghasilkan sisi tajaman. Sejauh ini, penelitian yang sudah dilakukan tidak menemukan artefak tulang dalam jumlah yang signifikan. Sedangkan pemanfaatan cangkang kerang (laut) lebih digunakan sebagai perhiasan, yaitu gelang dan bandul kalung. Gelang dan bandul yang ditemukan memiliki permukaan yang halus dan bentuk lingkaran sempurna. Hal tersebut menunjukkan adanya teknik pembuatan yang memperhatikan unsur seni untuk menghasilkan perhiasan. Dengan adanya bentuk perhiasan tersebut, menunjukkan bahwa seni kriya sangat diperhatikan. Hal itu senada dengan teknologi pembuatan wadah gerabah dengan motif hias dekoratif. Beragam motif hias tersebut menunjukkan bahwa keindahan dalam kriya sangat diperhatikan. Meskipun demikian, fragmen gerabah polos tanpa motif hias lebih mendominasi hasil ekskavasi. Pengamatan terhadap bentuk fragmen gerabah yang ditemukan menunjukkan bahwa wadah gerabah Gua Payung tampaknya lebih banyak digunakan untuk keperluan praktis sehari-hari. Fragmen bagian badan gerabah yang ditemukan umumnya tebal dan memiliki bekas hangus pada bagian luarnya. Berdasarkan pengamatan terhadap morfologinya, jenis wadah gerabah yang pernah digunakan di Gua Payung adalah kuali (Fajari 2010).

\section{Gua Payung dan Eksplorasi Sumberdaya Alam: Faktor Penyebab Kerusakan Situs}

Telah disebutkan di atas bahwa Gua Payung berada di gugusan bukit karst di Kecamatan Mantewe, tepatnya di Bukit Batu Tanjak, Desa Bulurejo. Ekosistem karst di Mantewe menjanjikan sejumlah sumberdaya alam yang dapat dimanfaatkan untuk kepentingan pembangunan ekonomi. Eksplorasi yang berlebihan terhadap sumberdaya tersebut dipastikan dapat menimbulkan ancaman kerusakan ekosistem karst dan berdampak pada perubahan lingkungan. Pemanfaatan sumberdaya alam yang telah banyak dilakukan di kawasan tersebut antara lain adalah sebagai berikut.

\section{Lahan Perkebunan Kelapa Sawit}

Pada saat ini, kawasan di Kecamatan Mantewe sedang marak dengan pembukaan kebun-kebun sawit baik oleh perusahaan swasta maupun masyarakat. Data statistik pada tahun 2010 menunjukkan bahwa angka pertumbuhan sektor pertanian di Kabupaten Tanah Bumbu didukung oleh peningkatan produksi subsektor perkebunan sebesar 7,71 \% terutama komoditas sawit dan karet. Peningkatan tersebut disebabkan adanya peningkatan konsumsi dunia terhadap kedua komoditas tersebut. Luas lahan sawit di Kalimantan Selatan telah mencapai 332 ribu hektar dengan jumlah produksi 3 ton/hektar. Dari total luas lahan tersebut, 17,6 \% berlokasi di Kabupaten Tanah Bumbu, yang menjadikannya sebagai lahan terluas nomor dua setelah Kabupaten Kotabaru (Irawan 2010).

Sehubungan dengan hasil yang menjanjikan, maka sawit menjadi primadona bagi masyarakat petani di wilayah Kecamatan Mantewe. Perkembangan kebun sawit di Mantewe semakin pesat dengan adanya rencana dari Pemerintah Kabupaten Tanah Bumbu yang akan mengadakan bantuan bibit kepada masyarakat petani (tanahbumbukab.go.id.htm). Di satu 
sisi, keberadaan kebun sawit dapat membantu peningkatan perekonomian masyarakat petani untuk tingkat yang lebih baik. Di sisi lain, faktor kerusakan lingkungan akibat pembukaan lahan secara besarbesaran untuk kebun sawit tentu dapat membawa dampak yang cukup serius. Salah satu dampak yang muncul adalah penambangan lapisan tanah di guagua kapur yang berada di lokasi pembukaan kebun sawit, seperti yang terjadi di Gua Payung di Desa Bulurejo, dan gugusan gua kapur di wilayah perkebunan milik perusahaan Rajawali Plantation di Desa Sukadamai.

Kasus yang terjadi di Gua Payung sangat memprihatinkan. Gua Payung yang pernah menjadi tempat tinggal pada masa prasejarah saat ini telah mengalami kerusakan parah akibat penambangan guano, tanah gua, serta batuan untuk keperluan pembukaan lahan kebun sawit (Foto 5). Ratusan bahkan ribuan data arkeologi yang berada pada lapisan tanah tersebut saat ini telah hilang. Hal tersebut disebabkan oleh adanya aktivitas penambangan guano (kotoran kelelawar) yang dimanfaatkan sebagai pupuk oleh petani sawit di kawasan Bulurejo. Berdasarkan pemaparan informan, penggalian dalam gua tidak hanya bertujuan untuk mengumpulkan guano saja, tetapi juga untuk menambang endapan tanah pada lantai gua (Foto 6). Tanah tersebut digunakan untuk mengurug lahan-lahan sawit yang baru dibuka. Menurut penuturan warga, tanah gua dianggap baik untuk pengolahan kebun sawit karena kandungan guano di dalamnya. Penggalian tanah di Gua Payung dilakukan pada seluruh permukaan lantai gua, dan hanya menyisakan sedikit bagian yang tidak turut digali. Warga menambang tanah dan guano secara berkelompok, dengan anggota antara 4-5 orang. Saat ini, hampir seluruh permukaan lantai Gua Payung telah ditambang secara besar-besaran. Ketebalan lapisan tanah yang hilang akibat ditambang berkisar antara 12 meter. Saat ini, fragmen gerabah dan alat litik yang tercecer dapat ditemukan dengan mudah baik di dalam gua maupun di lahan di sekitar Gua Payung.

Berdasarkan keterangan dari informan yang pernah turut dalam penambangan tanah gua, pada saat melakukan penggalian, mereka menemukan fragmen rangka manusia pada endapan tanah di dalam gua. Karena ketakutan, rangka tersebut kemudian dibuang. Informasi tersebut mengindikasikan bahwa Gua Payung sebenarnya dapat memberi petunjuk mengenai manusia pendukung budayanya. Sayang sekali, informasi mengenai keberadaan sisa manusia hanya sebatas ucapan lisan saja. Pada saat penelitian ini dilakukan, ekskavasi yang dilakukan di titik di mana rangka manusia pernah ditemukan pada saat penambangan tanah gua dilakukan (Kotak TP 4), tidak

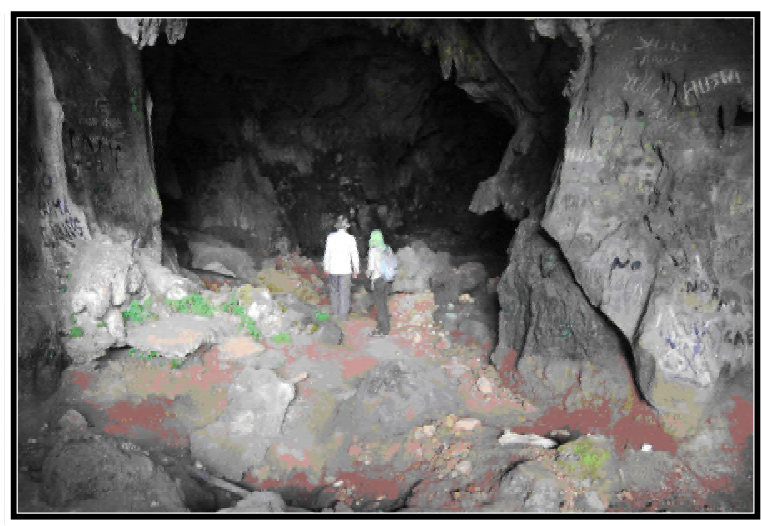

Foto 5. Gua Payung, terlihat lubang-lubang bekas galian masyarakat (Dok. Balai Arkeologi Banjarmasin, 2012).

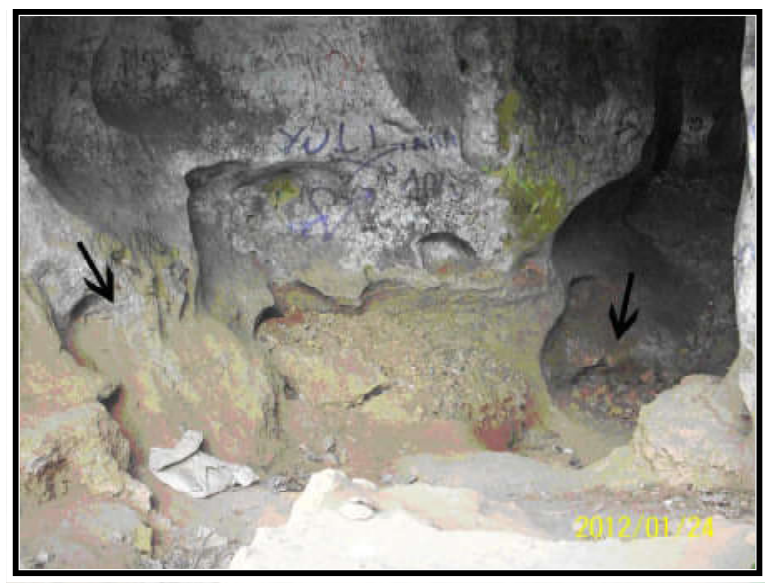

Foto 6. Tanda panah menunjukkan batas lantai gua sebelum digali oleh masyarakat (Dok. Balai Arkeologi Banjarmasin, 2012).

berhasil menemukan data yang diharapkan. Hal tersebut disebabkan oleh aktivitas penambangan yang telah mengambil sebagian besar tanah beserta rangkanya. Data arkeologi yang berhasil dikumpulkan pada lokasi tersebut berupa fragmen tulang binatang, fragmen gigi binatang, gerabah, dan litik serta cangkang kerang air tawar.

Kasus serupa juga terjadi di situs prasejarah Gua Babi dan Gua Tengkorak di Kabupaten Tabalong. Kedua gua tersebut merupakan gua hunian yang digunakan oleh manusia pada masa prasejarah yang pernah hidup sekitar 6000 tahun yang lalu. Di Gua Babi, banyak ditemukan peralatan manusia prasejarah yang berupa alat batu, alat tulang, dan alat kerang serta sisasisa makanan berupa himpunan tulang binatang dan cangkang. Sementara itu, di Gua Tengkorak ditemukan fragmen rangka manusia yang dikubur dengan posisi melipat. Hasil identifikasi menunjukkan bahwa rangka tersebut merupakan manusia dari ras Australomelanesoid berjenis kelamin perempuan (Widianto dan Handini 1999). Bukti-bukti kehadiran manusia prasejarah tersebut saat ini telah hilang akibat 
aktivitas pertambangan batu kapur dan kotoran kelelawar. Eksploitasi terhadap kedua sumberdaya tersebut menyebabkan kerusakan yang serius Situs Gua Babi dan Gua Tengkorak. Data yang tersisa saat ini adalah bekas lubang-lubang galian yang terdapat hampir di seluruh permukaan gua (Sugiyanto 2008, 134).

\section{Sumber Bahan Galian $C$ untuk Bangunan}

Bahan galian $\mathrm{C}$ adalah bahan yang tidak strategis dan vital yang tidak langsung mempengaruhi hajat hidup orang banyak, baik karena sifatnya maupun jumlah depositnya yang kecil (www.pustaka.pu.go.id/ new/istilah-bidang-detail. asp?id=1762). Pada Peraturan Pemerintah No 25 tahun 1964 pasal 1 disebutkan bahwa yang termasuk bahan galian $C$ adalah batu kapur, batu apung, tanah liat, batu pasir, dan bahan galian yang sejenis. Di kawasan Mantewe, terdapat sejumlah bahan galian $\mathrm{C}$ dalam jumlah yang melimpah, seperti ketersediaan batu gamping yang banyak ditemukan di bukit-bukit karst. Batu gamping merupakan salah satu bahan baku dalam produksi semen dan material bangunan. Oleh karena itu, selain penambangan tanah dan guano di dalam gua, warga juga melakukan penambangan batu gamping yang dimanfaatkan sebagai material bangunan.

Di Gua Payung, penambangan batu gamping dilakukan pada gugusan bukit karst di sekitar Bukit Batu Tanjak. Batu gamping tersebut digunakan oleh masyarakat sebagai bahan untuk pondasi bangunan. Meskipun dalam skala kecil, penambangan batu gamping yang terus-menerus dikhawatirkan dapat mengancam kelestarian ekosistem dan budaya di kawasan karst serta gua-gua yang mengandung data arkeologi. Selain di sekitar Gua Payung, penambangan batu gamping juga banyak dilakukan pada gugusan gua di perbukitan Liang Ulin yang berada dalam area lahan perusahaan perkebunan sawit Rajawali Plantation. Di beberapa lokasi terlihat bekas-bekas galian para penambang batu gamping dan tanah gua, serta kotoran kelelawar.

Potensi batu gamping sebagai bahan baku produksi semen di Kabupaten Tanah Bumbu saat ini belum terlalu dikembangkan. Pabrik semen yang sudah beroperasi di sekitar perbukitan karst Meratus berada di wilayah Kabupaten Kotabaru, yaitu di daerah Tarjun. Akan tetapi, tidak menutup kemungkinan munculnya eksploitasi batu gamping untuk produksi semen di kawasan Mantewe, mengingat ketersediaan sumber bahan dan tuntutan pembangunan ekonomi daerah. Deposit batu gamping di Tanah Bumbu terdapat di wilayah Kecamatan Simpang Empat (di Gunung Kangkalaan), Mantewe (Gunung Atasahu dan
Bulurejo), Kusan Hulu (Gunung Desa Guntung dan Teluk Kepayang), dan Satui di Gunung Desa Cuka (Anwar 2011, 102). Berdasarkan kajiannya, Arief Anwar $(2011,110)$ menyebutkan bahwa kawasan karst di Tanah Bumbu (Mantewe dan sekitarnya) merupakan daerah yang potensial untuk pengembangan industri semen.

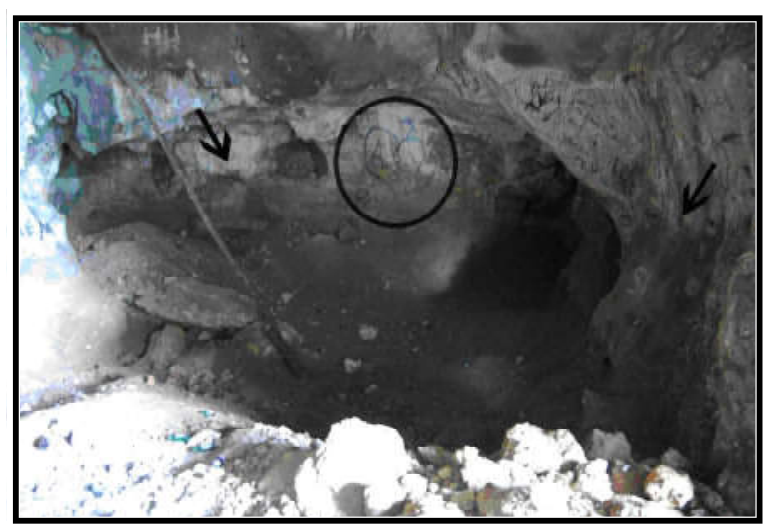

Foto 7. Gambar lingkaran menunjukkan aktivitas vandalisme berupa graviti liar, dan tanda panah menunjukkan batas permukaan gua sebelum digali

(Dok. Balai Arkeologi Banjarmasin, 2012).

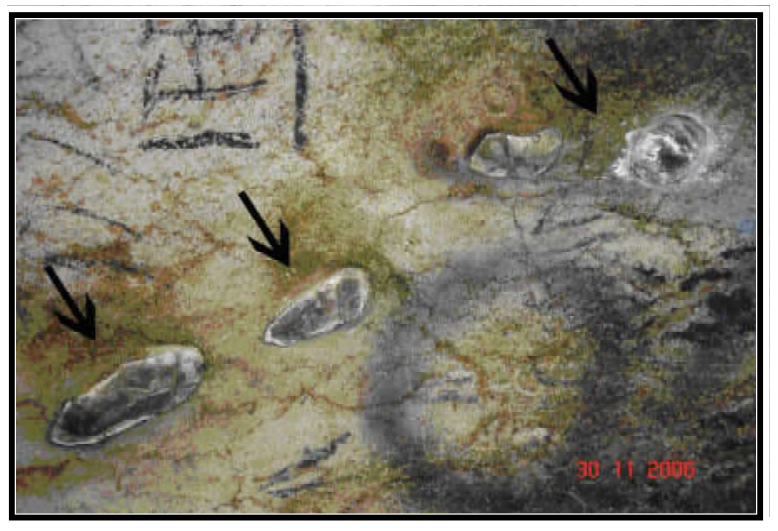

Foto 8. Tanda panah memperlihatkan bongkah rijang yang menempel pada dinding gua yang saat ini sudah dicongkel (Dok. Balai Arkeologi Banjarmasin, 2012).

\section{Aktivitas Vandalisme dalam Gua}

Dalam Kamus Besar Bahasa Indonesia vandalisme berarti perbuatan merusak dan menghancurkan hasil karya seni dan barang berharga lainnya (keindahan alam dan lain sebagainya) (www.kbbi.web.id). Bentuk vandalisme yang terjadi di Gua Payung yaitu, graviti liar pada dinding gua dan pencongkelan bongkahan-bongkahan batu rijang yang menempel di dinding gua (Foto 7 dan 8). Penggalian secara liar terhadap endapan tanah gua dan stalagmit serta stalagtit juga merupakan bentuk vandalisme yang umum terjadi. 


\section{Alur Sebab-Akibat Kerusakan Situs}

Kegiatan penambangan guano, tanah gua, dan batuan kapur serta aktivitas vandalisme di sekitar situs arkeologi tentunya tidak sejalan dengan amanat yang dikandung dalam UU Cagar Budaya No 11 tahun 2010 yang menyatakan bahwa kawasan karst yang memiliki gua/ceruk hunian masa prasejarah merupakan kawasan situs Cagar Budaya yang harus dilindungi dan dilestarikan. Hal tersebut juga bertentangan dengan Keputusan Menteri ESDM No 1456.K/20/MEM/2000 tentang Pedoman Pengelolaan Kawasan Karst yang menyebutkan bahwa kawasan karst yang mengandung peninggalan budaya termasuk dalam kawasan kelas I dan harus dilindungi. Pada pasal 14 disebutkan bahwa dalam kawasan kelas I tidak diperbolehkan ada kegiatan pertambangan ataupun kegiatan lain yang berpotensi merusak bentuk-bentuk karst baik di bawah maupun di atas permukaan (Sugiyanto 2008, 136).

Meskipun demikian, kerusakan masif yang terjadi di Situs Gua Payung dan sekitarnya tidak sepenuhnya merupakan kesalahan masyarakat yang melakukan aktivitas penambangan. Hal itu lebih diakibatkan karena beberapa faktor yang saling terkait, yang akan dijabarkan sebagai berikut.

\section{Publikasi Hasil Penelitian Arkeologi Kepada Masyarakat Luas}

Selama ini, penelitian arkeologi di Indonesia pada umumnya belum memiliki rumusan kebijakan yang berlaku umum sehingga peranan dan sumbangan hasil penelitian terhadap masyarakat belum dapat dirasakan (Kusumohartono 1995, 53). Pelaksanaan penelitian arkoelogi sendiri belum dilaksanakan secara terpadu sehingga tujuan dan paradigma arkeologi belum dapat dijelaskan secara terperinci. Kasus di Situs Gua Payung dan gua-gua di sekitarnya dapat menjadi gambaran kurangnya publikasi hasil penelitian kepada masyarakat yang berdampak pada kerusakan situs. Penelitian di Gua Payung dilakukan pertama kali pada 2006 dan baru ditindaklanjuti kembali pada tahun 2012. Berbagai artikel menyebutkan bahwa berdasarkan hasil penelitian tahun 2006, Gua Payung merupakan gua hunian prasejarah dengan tinggalan arfetak yang menakjubkan. Gua Payung dan kawasan karst di sekitarnya digadang-gadang akan memberikan sumbangan besar terhadap data kehidupan prasejarah yang masih minim di Kalimantan.

Hal tersebut menjadi sebuah ironi, ketika Situs Gua Payung diperkenalkan sebagai situs penting di kalangan arkeolog, masyarakat yang tinggal di dekat situs tersebut bahkan tidak mengetahui tentang keberadaan data arkeologi yang telah ditemukan. Mereka tidak mengerti bahwa aktivitas penambangan yang dilakukan telah menyebabkan hilangnya sejumlah data yang penting untuk mengungkapkan kehidupan awal di daerah tersebut. Fakta tersebut tentunya menjadi pekerjaan rumah yang besar bagi arkeolog untuk menyebarluaskan hasil penelitian arkeologi kepada masyarakat luas yang nantinya dapat memberikan pemahaman mengenai pentingnya menjaga kelestarian situs. Penyampaian hasil penelitian kepada masyarakat tentunya harus dilakukan dengan pendekatan yang berbeda dengan publikasi ilmiah yang selama ini sudah dilakukan. Bentuk penyampaian dapat berupa sosialisasi kepada warga di sekitar situs mengenai nilai penting data arkeologi yang ditemukan di daerahnya serta upaya untuk menjaga kelestariannya. Cerita bergambar mengenai sejarah masa lalu dapat menjadi bentuk publikasi popular dengan sasaran anak-anak usia sekolah.

\section{Ketidaktahuan Masyarakat Mengenai Potensi Arkeologi di Lingkungan Sekitarnya}

Publikasi hasil penelitian arkeologi yang tidak menyentuh masyarakat menyebabkan kurangnya pemahaman mereka terhadap pentingnya potensi arkeologi yang terdapat di sekitar tempat tinggalnya. Seperti halnya masyarakat penambang di sekitar Gua Payung, mereka menyebutkan bahwa ketika melakukan kegiatan penambangan pernah ditemukan sejumlah fragmen artefak tanah liat dan artefak batu, bahkan beberapa di antaranya menemukan rangka manusia. Akan tetapi, mereka sama sekali tidak memahami pentingnya sebuah fragmen gerabah ataupun sebongkah batu yang menurut arkeolog adalah hal yang sangat berharga. Ada beberapa orang warga yang menyimpan beliung persegi yang ditemukannya di endapan tanah Gua Payung. Hanya saja, alasan penyimpanan tersebut bukan karena beliung persegi dianggap sebagai sebuah artefak yang menjadi penanda sebuah masa penting pada masa lalu, namun lebih disebabkan karena bentuknya yang unik dan cerita-cerita mistik yang hampir selalu mewarnai kisah penemuannya.

Oleh karena itu, tidaklah mengherankan ketika pelaksanaan penelitian Situs Gua Payung pada 2012 mengetahui bahwa sebagian besar area gua telah rusak akibat aktivitas penambangan oleh masyarakat. Bahkan dinding-dinding gua tidak luput dari aksi vandalisme yang berupa graviti liar dan pencongkelan bongkah-bongkah batu rijang yang menempel. Hal tersebut disebabkan karena rentang penelitian yang begitu panjang tanpa ada sosialisasi terhadap masyarakat di sekitarnya mengenai keberadaan Gua Payung sebagai sebuah lokasi penting pada masa lalu.

Selain kurangnya publikasi hasil penelitian arkeologi, ketidaktahuan masyarakat tersebut 
disebabkan juga oleh tidak adanya sosialisasi Undang Undang tentang Cagar Budaya. Dalam Undang Undang Cagar Budaya No 11 tahun 2010 telah disebutkan mengenai definisi cagar budaya (Pasal 1), kriteria cagar budaya (Pasal 5, 6, 7, dan 8), kriteria situs dan kawasan cagar budaya (Pasal 9, 10, dan 11), larangan pengrusakan cagar budaya (Pasal 66 ayat 1), dan sanksi terhadap pengrusakan (Pasal 105). Hanya saja, poin-poin yang telah dijabarkan dalam Undang Undang tersebut nampaknya sama sekali belum menyentuh kalangan masyarakat di sekitar Situs Gua Payung. Sebagian besar masyarakat yang bermata pencaharian sebagai petani sawit dan mengandalkan sumberdaya lingkungan untuk hidup tidak memiliki akses untuk lebih memahami arti pentingnya cagar budaya seperti yang telah diamanatkan dalam Undang Undang tersebut. Akibat dari ketidakpahaman tersebut, tidak ada rasa memiliki dan keinginan untuk menjaga kelestarian Situs Gua Payung dan sekitarnya. Aktivitas-aktivitas penambangan dan perkebunan yang merusak situs akan tetap dilakukan dalam rangka pemenuhan kebutuhan ekonomi mereka.

\section{Perhatian Pemerintah Terhadap Keberlang- sungan Situs-situs Arkeologi}

Kedua poin yang telah dijelaskan sebelumnya, diperparah oleh kurangnya perhatian dari instansi pemerintah, dalam hal ini Pemerintah Daerah setempat dan jajarannya terhadap situs-situs budaya di daerahnya. Saat ini, budaya sedang digadanggadang sebagai salah satu pijakan untuk pembentukan karakter dan jati diri bangsa. Akan tetapi, hal tersebut belum terimplementasikan dalam program-program pemerintah di daerah. Kerjasama yang ditawarkan oleh instansi arkeologi terkadang seperti tidak disambut oleh pimpinan daerah. Hal ini mungkin dapat dipahami, mengingat di dalam Negara berkembang seperti Indonesia, aktivitas pembangunan industri cenderung memiliki posisi yang lebih unggul daripada pembangunan pengetahuan dan budaya. Implikasinya adalah dalam kebijakan pembangunan ekonomi di daerah maupun pusat selalu diutamakan, sedangkan sumberdaya untuk pengetahuan cenderung dikesampingkan (Kusumohartono 1995, 46).
Selain kasus di Gua Payung, telah banyak kasus hilangnya situs budaya tua sebagai dampak dari aktivitas industri dan pembangunan ekonomi, di antaranya yaitu Situs Awang Bangkal di Kabupaten Banjar, Gua Babi dan Gua Tengkorak di Kabupaten Tabalong, dan Situs Jambu Hilir di Kabupaten Hulu Sungai Selatan. Kawasan-kawasan tersebut memang belum ditetapkan sebagai situs/kawasan Cagar Budaya sehingga perusakan yang terjadi tidak dapat ditindak secara hukum. Belum adanya payung hukum yang melindungi situs-situs arkeologi menjadi pekerjaan rumah tersendiri bagi pihak terkait (dalam hal ini Balai Arkeologi Banjarmasin, Balai Pelestarian Cagar Budaya Samarinda dan pemerintah daerah setempat). Penetapan kawasan karst Mantewe sebagai kawasan Cagar Budaya perlu segera dilakukan untuk melindungi data-data arkeologi yang ada di dalamnya.

Bagan alur sebab-akibat tersebut dapat digambarkan dalam diagram berikut ini.

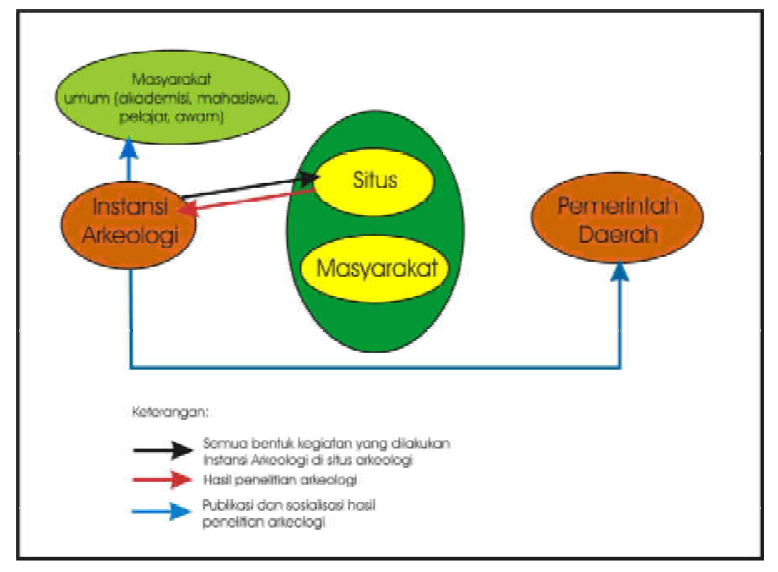

Gambar 1. Skema interaksi tanpa melibatkan masyarakat di sekitar situs

Pada skema di atas dapat dilihat bahwa masyarakat yang bersentuhan langsung dengan situs arkeologi selalu berada dalam posisi yang terabaikan. Penelitian arkeologi seolah hanya berusaha untuk memecahkan permasalahan mengenai situs itu sendiri tanpa banyak memikirkan mengenai masyarakat di sekitarnya. Memang, masyarakat seringkali dilibatkan dalam kegiatan penelitian. Akan tetapi pelibatan tersebut hanya sebatas sebagai tenaga lokal untuk

3 Situs Awang Bangkal merupakan situs paleolitik tertua yang pernah ditemukan di Kalimantan Selatan. Situs ini berada pada tepian aliran Sungai Riam Kanan yang saat ini telah tenggelam setelah pembangunan waduk Riam Kanan untuk kepentingan Pembangkit Listrik Tenaga Air pada tahun 1973.

$4 \quad$ Situs tersebut merupakan situs hunian manusia prasejarah dari Australomelanesid yang hidup pada 6000 tahun yang lalu. kerusakan situs disebabkan oleh aktivitas penambangan batu kapur dan kotoran kelelawar baik oleh masyarakat perorangan ataupun perusahaan swasta.

5 Situs Jambu Hilir merupakan situs pemukiman tua yang berada di area terbuka pada aliran Sungai Rangas dengan angka tahun sekitar 3000 tahun yang lalu (Anggraeni dan Sunarningsih 2008). Saat ini sebagian areal situs telah tergusur oleh pembangunan saluran irigasi. 
membantu kegiatan penelitian. Hasil penelitian arkeologi yang berupa publikasi ilmiah biasanya akan dikirimkan kepada masyarakat luas melalui sekolah, universitas, perpustakaan daerah, serta Pemerintah Daerah sebagai laporan atas ijin penelitian yang sudah dikeluarkan. Sebagian besar di antaranya bahkan telah diterbitkan melalui media internet sehingga lebih banyak kalangan yang dapat mengakses hasil penelitian. Tetapi bagaimana dengan masyarakat di sekitar situs, yang pada umumnya berada di daerah yang tidak terjangkau oleh jaringan internet? Seperti halnya masyarakat di sekitar Situs Gua Payung, yang berada di Desa Bulurejo. Lokasi desa tersebut berada jauh di daerah pedalaman dengan sarana transportasi yang sangat minim dan hampir tidak tersentuh akses internet.

Publikasi arkeologi mengenai pentingnya Gua Payung tidak pernah tersampaikan kepada mereka, sehingga kebanggaan terhadap aset budaya tidak pernah muncul. Sosialisasi hasil penelitian yang dilakukan oleh instansi arkeologi kepada Pemerintah Daerah seolah berhenti dan tidak tersalurkan kepada masyarakat. Demikian pula dalam kegiatan pelestarian situs, aspirasi masyarakat seringkali dikesampingkan dan belum sepenuhnya didorong partisipasinya (Sulistyanto 2009, 259).

Hal tersebut dapat diatasi dengan lebih merangkul masyarakat di sekitar situs. Di atas kertas, hal itu seolah mudah untuk dilaksanakan dengan menambahkan garis timbal-balik pada diagram sebelumnya untuk menunjukkan peran dan keterlibatan masyarakat selama pelaksanaan penelitian sampai pada menjaga kelestarian situs. Namun, dalam proses yang sesungguhnya, menumbuhkan pemahaman dan kesadaran untuk turut menjaga kelestarian situs tentu tidaklah semudah membalikkan telapak tangan. Wasita (2007, 120-121) menyebutkan bahwa pemahaman masyarakat terhadap tinggalan dan situs arkeologi sangatlah beragam, sehingga untuk menyentuh mereka supaya berkontribusi dalam pelestarian situs merupakan suatu masalah. Untuk mengatasinya, Wasita mengajukan beberapa saran, yaitu (1) penyuluhan hukum kepada masyarakat di sekitar situs sebagai dasar pemahaman akan pentingnya situs cagar budaya; (2) menjadikan situs sebagai bagian dari kepentingan masyarakat; (3) menjadikan masyarakat sebagai bagian dari pengelola

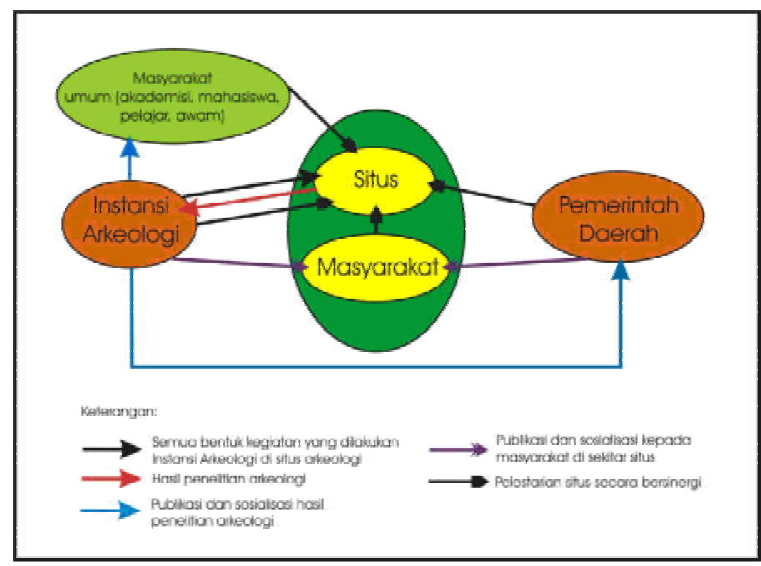

Gambar 2. Skema interaksi dengan melibatkan masyarakat situs

sumberdaya arkeologi; dan (4) memanfaatkan kearifan nilai-nilai leluhur sebagai pembelajaran kepada masyarakat untuk menumbuhkan kebanggaan terhadap situs budaya (Wasita 2007, 124-127).

Sementara itu, pemahaman Pemerintah Daerah mengenai tinggalan dan situs arkeologi tidaklah jauh berbeda dengan masyarakat, mengingat arkeologi merupakan disiplin ilmu yang spesifik. Harus diakui, lulusan arkeologi saat ini belum banyak ditempatkan pada posisi-posisi strategis dalam kebijakan pembangunan Pemerintah Daerah. Hal tersebut dapat diatasi dengan melakukan focus group discussion ${ }^{6}$ (FGD) secara bertahap yang melibatkan instansi arkeologi dan akademisi, pemerintah daerah, dan masyarakat di sekitar situs. Dalam tulisan ini, kasus yang dijadikan studi adalah kelestarian situs-situs arkeologi di kawasan karst Mantewe dan sekitarnya. Pihak-pihak yang harus dilibatkan yaitu Balai Arkeologi Banjarmasin selaku instansi pemerintah yang berwenang dalam penelitian arkeologi, Pemerintah Daerah Kabupaten Tanah Bumbu dan jajarannya (Bapedda Kabupaten Tanah Bumbu, Dinas Kebudayaan, Pariwisata, Pemuda dan Olah Raga Kabupaten Tanah Bumbu, Kecamatan Mantewe, kepala desa setempat), masyarakat umum di sekitar situs, dan Balai Pelestarian Cagar Budaya Samarinda.

Penelitian arkeologi yang telah dilakukan beberapa kali di kawasan tersebut, di antaranya yaitu Situs Gua Payung di Desa Bulurejo $(2006,2012)$, Situs Ceruk Bangkai di Desa Dukuh Rejo (2008, 2010, 2012, 2013), dan Situs Liang Ulin 2 di Desa Sukadamai (2012, 2013) menunjukkan bahwa kawasan karst Mantewe

$6 \quad$ Focus Group Discussion adalah diskusi terkelompok antara beberapa individu yang berinteraksi dan memiliki persamaan karakteristik, yang dipandu oleh moderator yang menggunakan interaksi dalam kelompok sebagai alat untuk mengumpulkan sejumlah informasi mengenai suatu masalah atau topik tertentu (Marczak dan Sewell 2013). Menurut Krueger (1988, dalam Marczak dan Sewell 2013), tahapan yang dilakukan dalam FGD adalah (1) penyusunan konsep diskusi, yang meliputi penentuan tujuan, subjek studi, dan rencana serta perlengkapan; (2) tahap diskusi, yang meliputi penyusunan pertanyaan sesuai dengan permasalahan, penetapan moderator yang memiliki kemampuan mengakomodir jalannya diskusi, dan penetapan peserta diskusi; dan (3) tahap analisis data dan pelaporan. 
merupakan kawasan cagar budaya yang penting. Hal tersebut menjadi tema dasar untuk proses forum group discussion yang sebaiknya segera dilaksanakan, mengingat ancaman terhadap kerusakan situs yang semakin meluas. Gambaran model pelaksanaan FGD yang bisa dilakukan dapat diilustrasikan sebagai berikut.

FGD I, antara Balai Arkeologi Banjarmasin dengan warga di sekitar situs yang bisa diwakili oleh tokoh masyarakat atau tokoh adat yang memiliki pengaruh. Dalam diskusi ini, tujuan yang akan dicapai adalah pendapat masyarakat. Selain itu, Balai Arkeologi Banjarmasin selaku fasilitator perlu menyampaikan sosialisasi hasil penelitian yang sudah dilaksanakan dan arti penting situs-situs arkeologi di kawasan Mantewe serta poin-poin penting mengenai Cagar Budaya yang telah dirumuskan dalam Undang Undang No 11 tahun 2010.

FGD II, antara Balai Arkeologi Banjarmasin dengan jajaran Pemerintah Daerah Kabupaten Tanah Bumbu. Dalam diskusi ini, tujuan yang akan dicapai adalah pendapat pemerintah daerah sebagai stake holder mengenai penelitian arkeologi di kawasan Mantewe dan arti keberadaan situs-situs arkeologi yang telah ditemukan. Bersama dengan hasil dari FGD I, hasil dari diskusi tersebut menjadi salah satu dasar pertimbangan dalam penyusunan konsep pelestarian kawasan yang diinginkan.

FGD III, antara Balai Arkeologi Banjarmasin dengan perwakilan masyarakat sekitar situs, jajaran Pemerintah Daerah Kabupaten Tanah Bumbu, dan Balai Pelestarian Cagar Budaya Samarinda. Dalam diskusi ini, tujuan yang akan dicapai adalah bentuk pelestarian kawasan situs budaya di Kecamatan Mantewe dan sekitarnya yang dapat diterima oleh semua pihak. Hasil dari diksusi I yang merangkum pendapat dan keinginan masyarakat di sekitar situs dan diskusi Il yang merupakan pendapat dan kebijakan pemerintah daerah adalah dasar bagi fasilitator (dalam hal ini Balai Arkeologi Banjarmasin) untuk menyusun dan merencanakan tahapan diskusi ini. Dengan melakukan tahap-tahapan diskusi di atas, diharapkan dapat meminimalisir konflik kepentingan yang umumnya muncul dalam proses pengelolaan dan pelestarian cagar budaya.

\section{E. Penutup}

Faktor penyebab kerusakan yang terjadi di Gua Payung, serta gua-gua hunian lainnya di kawasan karst Mantewe tidak semata-mata disebabkan oleh satu pihak saja. Kerusakan-kerusakan yang terjadi seringkali muncul sebagai sebab dan akibat dari beberapa hal yang saling terkait satu sama lain. Tidak adanya publikasi hasil penelitian arkeologi terhadap masyarakat di sekitar Gua Payung menyebabkan mereka tidak memahami makna dan nilai penting Gua Payung sebagai lokasi yang menyimpan sejarah budaya masa lalu. Hal tersebut menyebabkan masyarakat tidak merasa berat untuk mengeksploitasi sumberdaya lingkungan di sekitar situs untuk memenuhi kebutuhan ekonominya. Selain itu, kerusakan yang terjadi juga disebabkan oleh kurangnya perhatian pemerintah daerah setempat terhadap keberadaan situs-situs arkeologi di kawasan tersebut. Sekali lagi, ketiadaan perhatian tersebut bukan tidak mungkin disebabkan karena kurangnya publikasi hasil penelitian kepada pemerintah daerah dan jajarannya.

Hal tersebut menjadi tantangan tersendiri bagi instansi arkeologi, dalam hal ini Balai Arkeologi Banjarmasin, untuk lebih menyuarakan hasil-hasil penelitian arkeologi secara lebih luas, di luar publikasi ilmiah yang sudah dilakukan. Publikasi popular melalui cerita bergambar dapat menjadi salah satu alternatif penyebarluasan hasil penelitian arkeologi, dengan anak usia sekolah sebagai sasarannya. Sosialisasi pasca kegiatan penelitian juga sebaiknya dilakukan supaya masyarakat mengetahui tentang keberadaan data arkeologi di sekitarnya. Penyebarluasan hasil penelitian arkeologi diharapkan dapat membawa masyarakat di sekitar situs dan pemerintah di daerah untuk lebih memahami nilai penting data arkeologi dan situs cagar budaya sebagai sesuatu yang harus dilindungi dan dilestarikan. Pemahaman yang baik diharapkan menjadi landasan bagi pemerintah daerah setempat untuk mengeluarkan regulasi mengenai keberadaan situs arkeologi di wilayahnya. Regulasi tersebut dapat berupa Surat Keputusan (SK) atau Peraturan Daerah yang menetapkan suatu lokasi dengan tinggalan arkeologi sebagai situs atau kawasan Cagar Budaya. Untuk kasus Gua Payung dan gua-gua di sekitarnya yang mengandung tinggalan arkeologi sudah semestinya direkomendasikan untuk segera ditetapkan sebagai situs/kawasan Cagar Budaya. 


\section{Referensi}

Anggraeni dan Sunarningsih. 2008. The prehistoric settlement at Jambu Hilir, South Kalimantan Province, Indonesia. Bulletin of the Indo-Pacific Prehistory Association 28: 120-126.

Anwar, Arief. 2011. Kajian potensi bahan baku semen di Kalimantan Selatan. Jurnal Kebijakan Pembangunan 6(2): 98-111.

Fajari, Nia Marniati Etie. 2010. Gerabah Gua Payung: jejak-jejak Austronesia di Kalimantan bagian selatan. Naditira Widya 4(1):11-24.

Fajari, Nia Marniati Etie dan Vida Pervaya Rusianti Kusmartono. 2012. Excavation of Gua Payung on the southern karstic zone of Meratus Mountain, South Kalimantan Province, Indonesia. Granucci Grant 2011 Final Report. Belum diterbitkan.

Irawan, Miyan Andi. 2010. Tinjauan perekonomian Tanah Bumbu tahun 2010. Diunduh dari www.tanahbumbu.go.id, tanggal 27 Februari 2013.

Kusumohartono, Bugie. 1995. Penelitian arkeologi dalam konteks pengembangan sumberdaya arkeologi. Berkala Arkeologi XIII: 46-57.

Marzcak, Mary dan Meg Sewell. 2013. Using Focus Groups For Evaluation. Diunduh dari www.ag.arizona.edu/sfcs/cyfernet/cyfar/ focus.htm, tanggal 9 Maret 2013.
Samodra, Hanang. 2001. Nilai strategis kawasan karst di Indonesia. Bandung: Pusat Penelitian dan Pengembangan Geologi Departemen Energi dan Sumberdaya Mineral.

Sugiyanto, Bambang. 2008. Pengelolaan kawasan karstt di Kalimantan Selatan. Naditira Widya 2(1): 132-141.

Sulistyanto, Bambang. 2009. Konflik sumberdaya arkeologi pada era otonomi daerah. Naditira Widya 3(2): 253-267.

Wasita. 2007. Memposisikan masyarakat sebagai garda depan pelestarian sumber daya arkeologi. Naditira Widya 1(1): 120-130.

Pemerintah Republik Indonesia. 2010. UndangUndang nomor 11 tahun 2010 tentang Cagar Budaya.

Pemerintah Rebuplik Indonesia. 2000. Keputusan Menteri ESDM No. 1456.K/20/MEM/2000 tentang Pedoman Pengelolaan Kawasan Karst.

Pemerintah Republik Indonesia. 2008. Peraturan Pemerintan No 26 tahun 2008 tentang Rencana Tata Ruang Wilayah Nasional.

Pemerintah Republik Indonesia. 1964. Peraturan Pemerintan No 25 tahun 1964 tentang Penggolongan Bahan-bahan Galian.

www.kbbi.web.id, diakses tanggal 8 Maret 2013

www.pustaka.pu.go.id/new/istilah-bidangdetail.asp?id=1762, diakses tanggal 8 Maret 2013.

\section{Daftar Informan}

\begin{tabular}{|c|c|c|c|}
\hline Nama & : Bapak Wanto & Nama & : Bapak Samino \\
\hline Pekerjaan & : Petani & Pekerjaan & : Ketua RT \\
\hline Alamat & : Bulurejo & Alamat & : Bulurejo \\
\hline Nama & Bapak Jumiri & Nama & : Bapak Khairani \\
\hline Pekerjaan & : Sekretaris Desa & Pekerjaan & : buruh sawit \\
\hline Alamat & : Bulurejo & Alamat & : Mantewe \\
\hline Nama & : Bapak Suratin & & \\
\hline Pekerjaan & : petani & & \\
\hline Alamat & : Bulurejo & & \\
\hline
\end{tabular}

